Interaction with simple monopyridinecarboxylic ligands reveals unexpected structural types of uranyl halides

Grigory Andreev*, Nina Budantseva, Aleksander Fedoseev

Supporting Information

Experimental Details

Caution: Although the uranium trioxide used in this experiment contains depleted uranium, standard precautions for handling radioactive materials should be observed. All uraniumcontaining materials were handled in the laboratory specially designated for the study of radioactive materials. Hydrofluoric acid is acutely toxic and corrosive, and must be handled with extreme caution. Appropriate personal protective equipment should be worn at all times when handling HF, and proper technique for using HF safely should always be followed.

Synthesis. Uranium trioxide, hydrofluoric, hydrochloric, hydrobromic, picolinic, nicotinic, and isonicotinic acids were obtained from commercial sources and used without further purification. Uranium trioxide $(20 \mathrm{mg}, 0.07 \mathrm{mmol})$ was dissolved in an excess of $1 \mathrm{M}$ hydrofluoric, $1 \mathrm{M}$ hydrochloric, or $1 \mathrm{M}$ hydrobromic acid. The obtained solutions were evaporated at a temperature below $120^{\circ} \mathrm{C}$, and the precipitate was dissolved in a minimal amount of water $(1 \mathrm{ml})$. For the synthesis of compounds $1-4$, the solid picolinic, nicotinic, or isonicotinic acid (43 $\mathrm{mg}, 0.35 \mathrm{mmol}$ ) was added to the corresponding solution of uranyl fluoride, chloride or bromide. The obtained suspensions were placed in sealed glass tubes and heated at $130^{\circ} \mathrm{C}$ for 6 hours. After cooling to room temperature, yellow crystals of compounds 1-4 suitable for the X-ray analysis were obtained.

$X$-ray diffractometry. The data were collected on Bruker KAPPA APEX II diffractometer with $\mathrm{CCD}$ area detector using graphite monochromated $\operatorname{MoK}_{\alpha}(\lambda=0.71073 \AA)$ radiation at $\mathrm{T}=100 \mathrm{~K}$. The SAINT program was used to integrate the diffraction profiles, and the data were corrected for Lorentz and polarization effects as well as for absorption using SADABS [1]. The crystal structures were solved by direct methods and refined by full-matrix least-squares refinement against $F^{2}$ using SHELXTL software [2]. All non-hydrogen atoms were located, and their positions were refined anisotropically, except the atoms of the disordered cations. The hydrogen atoms were placed in the geometrically calculated positions. The hydrogen atoms of water molecules of crystallization were not localized. The main crystal data and details of the final refinement calculations are indicated in Table S1. The main interatomic distances are listed in Tables S2 - S5. 
Spectroscopy. Infrared and optical spectra of polycrystalline compounds were collected at room temperature on Shimadzu IR Prestige 21 and Shimadzu UV3100 spectrometers, respectively. The samples for measurements were prepared by a standard technique in $\mathrm{NaCl}$ pellets. The amount of compounds in the pressed pellet was $\sim 1 \%$ by weight for infrared and $\sim 5-10 \%$ by weight for visible spectra measurements. The photoluminescence spectra were measured using Avantes ULS2048L spectrometer, with LED excitation source $(\lambda=350 \mathrm{~nm})$.

Table S1. Crystal Data and Details of Final Refinement Calculations for Compounds 1-4

\begin{tabular}{|c|c|c|c|c|}
\hline & 1 & 2 & 3 & 4 \\
\hline Space group & $\mathrm{P} 4{ }_{1} 212$ & Pnma & P-1 & Pbca \\
\hline$a, \AA$ & $9.1770(5)$ & $18.2830(4)$ & $8.6992(6)$ & $12.1764(9)$ \\
\hline$b, \AA$ & $9.1770(5)$ & 17.0783(5) & $12.5165(9)$ & $15.3498(12)$ \\
\hline$c, \AA$ & 26.4017(15) & $6.9480(2)$ & $14.3740(9)$ & $18.6039(14)$ \\
\hline$\alpha,{ }^{\circ}$ & 90 & 90 & $99.735(1)$ & 90 \\
\hline$\beta,^{\circ}$ & 90 & 90 & $90.276(1)$ & 90 \\
\hline$\gamma,{ }^{\circ}$ & 90 & 90 & $96.293(2)$ & 90 \\
\hline$V, \AA^{3}$ & $2223.5(3)$ & 2169.46(10) & $1532.82(18)$ & $3477.2(5)$ \\
\hline$Z$ & 4 & 4 & 2 & 8 \\
\hline No. of reflections & 23217 & 31634 & 23660 & 45346 \\
\hline $\begin{array}{l}\text { No. of unique } \\
\text { reflections }\end{array}$ & 4365 & 4315 & 11805 & 6714 \\
\hline No. of parameters & 132 & 146 & 416 & 235 \\
\hline$R$ & 0.042 & 0.025 & 0.037 & 0.038 \\
\hline$w \mathrm{R}\left(F^{2}\right)$ & 0.099 & 0.044 & 0.071 & 0.098 \\
\hline $2 \theta,^{\circ}$ & 65 & 65 & 65 & 65 \\
\hline
\end{tabular}


Table S2. Main Interatomic Distances $(\AA)$ in the Structure of $\left[\left(\mathrm{UO}_{2}\right)_{2} \mathrm{Br}_{4}(\mathrm{HPic})_{2}\left(\mathrm{H}_{2} \mathrm{O}\right)\right]$

\begin{tabular}{llll}
\hline $\mathrm{U} 1-\mathrm{O} 1$ & $1.764(8)$ & $\mathrm{U} 2-\mathrm{O} 2$ & $1.773(8)$ \\
$\mathrm{U} 1-\mathrm{O} 4$ & $2.370(8)$ & $\mathrm{U} 2-\mathrm{O} 3$ & $2.319(7)$ \\
$\mathrm{U} 1-\mathrm{O} 5$ & $2.504(11)$ & $\mathrm{U} 2-\mathrm{Br} 2$ & $2.8076(11)$ \\
$\mathrm{U} 1-\mathrm{Br} 1$ & $2.9166(11)$ & & \\
\hline
\end{tabular}

Table S3. Main Interatomic Distances $(\AA)$ in the Structure of $\left[\left(\mathrm{UO}_{2}\right)_{2} \mathrm{Br}_{4}(\mathrm{HNic})_{2}\left(\mathrm{H}_{2} \mathrm{O}\right)\right]$

\begin{tabular}{llll}
\hline $\mathrm{U} 1-\mathrm{O} 1$ & $1.756(3)$ & $\mathrm{U} 2-\mathrm{O} 3$ & $1.765(4)$ \\
$\mathrm{U} 1-\mathrm{O} 2$ & $1.765(3)$ & $\mathrm{U} 2-\mathrm{O} 4$ & $1.758(4)$ \\
$\mathrm{U} 1-\mathrm{O} 6$ & $2.383(3)$ & $\mathrm{U} 2-\mathrm{O} 5$ & $2.305(3)$ \\
$\mathrm{U} 1-\mathrm{O} 7$ & $2.484(4)$ & $\mathrm{U} 2-\mathrm{Br} 2$ & $2.8038(4)$ \\
$\mathrm{U} 1-\mathrm{Br} 1$ & $2.9091(4)$ & & \\
\hline
\end{tabular}

Table S4. Main Interatomic Distances $(\AA)$ in the Structure of $\left[\mathrm{UO}_{2} \mathrm{Cl}(\mathrm{HisoNic})_{3}\right]\left[\mathrm{UO}_{2} \mathrm{Cl}_{3}(\mathrm{HisoNic})\right]$

\begin{tabular}{llll}
\hline $\mathrm{U} 1-\mathrm{O} 1$ & $1.778(3)$ & $\mathrm{U} 2-\mathrm{O} 11$ & $1.763(3)$ \\
$\mathrm{U} 1-\mathrm{O} 2$ & $1.770(3)$ & $\mathrm{U} 2-\mathrm{O} 12$ & $1.775(3)$ \\
$\mathrm{U} 1-\mathrm{O} 4$ & $2.347(3)$ & $\mathrm{U} 2-\mathrm{O} 10$ & $2.293(3)$ \\
$\mathrm{U} 1-\mathrm{O} 6$ & $2.304(3)$ & $\mathrm{U} 2-\mathrm{Cl} 2$ & $2.6476(11)$ \\
$\mathrm{U} 1-\mathrm{O} 7$ & $2.533(3)$ & $\mathrm{U} 2-\mathrm{Cl} 3$ & $2.6933(11)$ \\
$\mathrm{U} 1-\mathrm{O} 8$ & $2.471(3)$ & $\mathrm{U} 2-\mathrm{Cl} 4$ & $2.6666(11)$ \\
$\mathrm{U} 1-\mathrm{Cl1}$ & $2.6825(12)$ & & \\
\hline
\end{tabular}

Table S5. Main Interatomic Distances (A) in the Structure of $\left[\left(\mathrm{UO}_{2}\right)_{3} \mathrm{~F}_{6}(\mathrm{HisoNic})\left(\mathrm{H}_{2} \mathrm{O}\right)\right] \cdot \mathrm{H}_{2} \mathrm{O}$

\begin{tabular}{llllll}
\hline $\mathrm{U} 1-\mathrm{O} 1$ & $1.768(5)$ & $\mathrm{U} 2-\mathrm{O} 3$ & $1.764(6)$ & $\mathrm{U} 3-\mathrm{O} 5$ & $1.762(5)$ \\
$\mathrm{U} 1-\mathrm{O} 2$ & $1.763(5)$ & $\mathrm{U} 2-\mathrm{O} 4$ & $1.752(6)$ & $\mathrm{U} 3-\mathrm{O} 6$ & $1.769(5)$ \\
$\mathrm{U} 1-\mathrm{F} 1$ & $2.273(4)$ & $\mathrm{U} 2-\mathrm{F} 1$ & $2.298(4)$ & $\mathrm{U} 3-\mathrm{F} 3$ & $2.308(4)$ \\
$\mathrm{U} 1-\mathrm{F} 2$ & $2.279(4)$ & $\mathrm{U} 2-\mathrm{F} 2$ & $2.293(4)$ & $\mathrm{U} 3-\mathrm{F} 4$ & $2.369(4)$ \\
$\mathrm{U} 1-\mathrm{F} 3$ & $2.283(4)$ & $\mathrm{U} 2-\mathrm{F} 5$ & $2.315(4)$ & $\mathrm{U} 3-\mathrm{F} 4$ & $2.387(4)$ \\
$\mathrm{U} 1-\mathrm{O} 7$ & $2.461(5)$ & $\mathrm{U} 2-\mathrm{F} 6$ & $2.323(4)$ & $\mathrm{U} 3-\mathrm{F} 5$ & $2.288(4)$ \\
$\mathrm{U} 1-\mathrm{O} 8$ & $2.470(4)$ & $\mathrm{U} 2-\mathrm{O} 9$ & $2.449(5)$ & $\mathrm{U} 3-\mathrm{F} 6$ & $2.295(4)$ \\
\hline
\end{tabular}




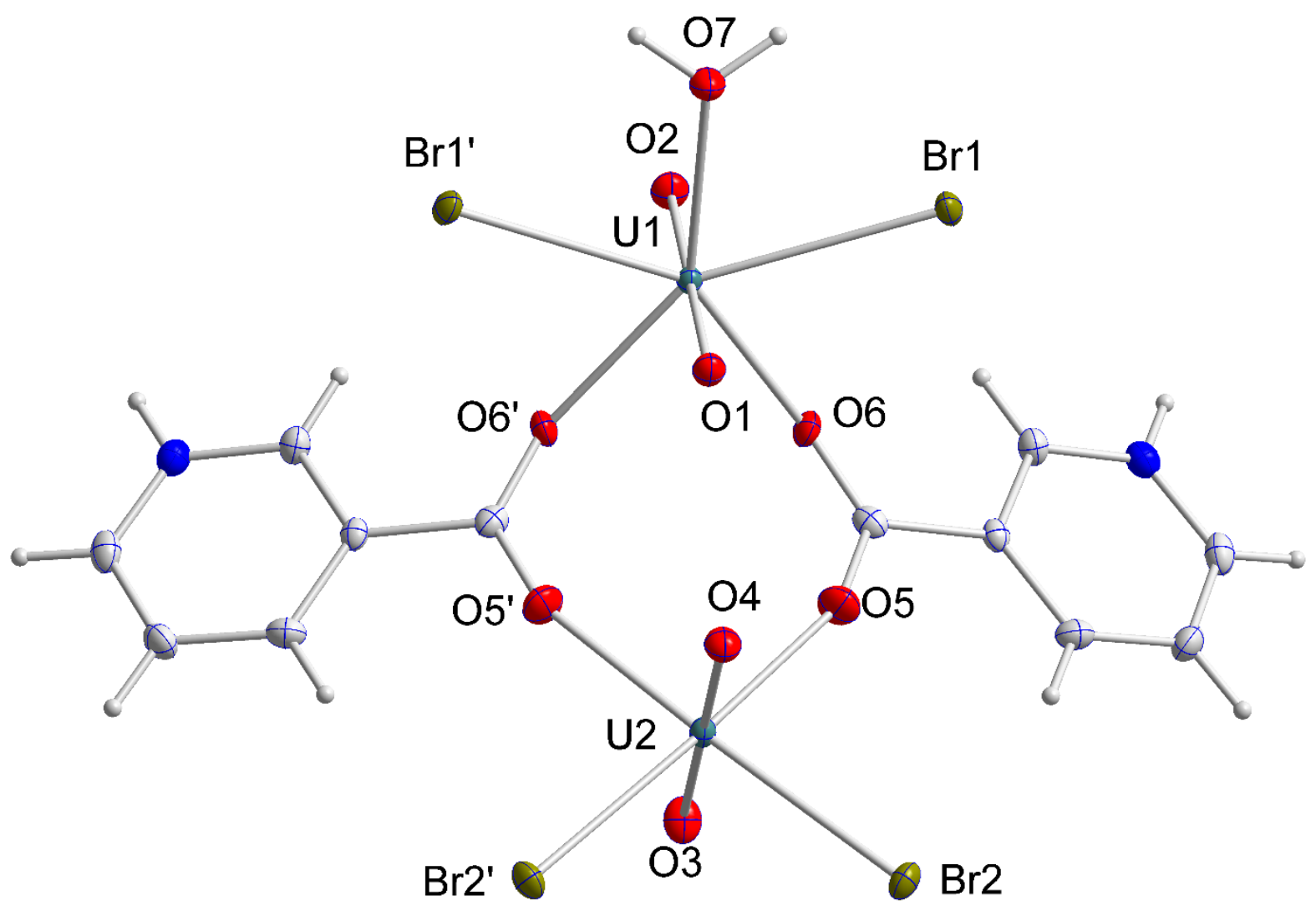

Figure S1. Thermal ellipsoid representation of the $\left[\left(\mathrm{UO}_{2}\right)_{2} \mathrm{Br}_{4}(\mathrm{HPic})_{2}\left(\mathrm{H}_{2} \mathrm{O}\right)\right]$ dinuclear unit in the structure of compound 1 


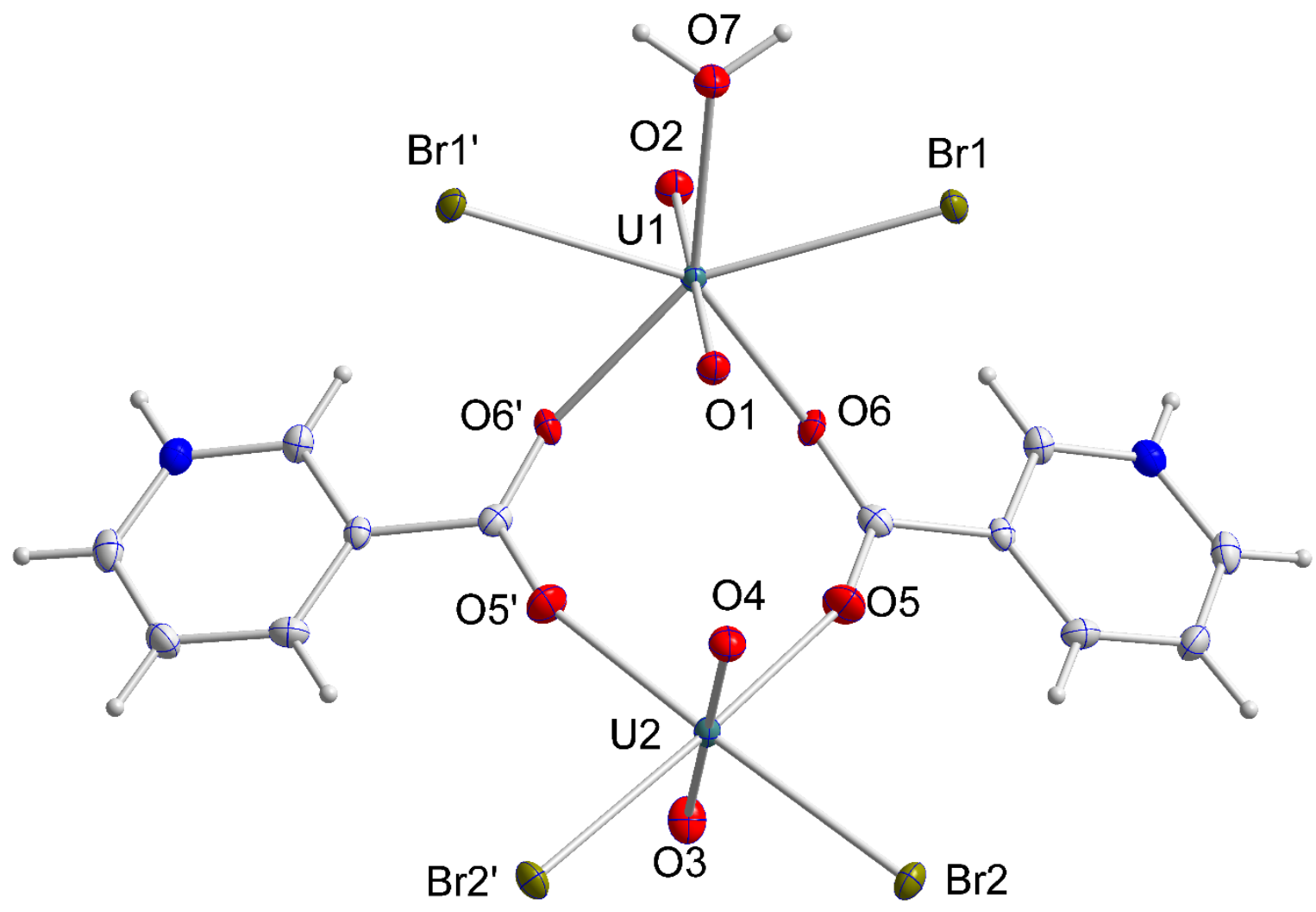

Figure S2. Thermal ellipsoid representation of the $\left[\left(\mathrm{UO}_{2}\right)_{2} \mathrm{Br}_{4}(\mathrm{HNic})_{2}\left(\mathrm{H}_{2} \mathrm{O}\right)\right]$ dinuclear unit in the structure of compound 2 


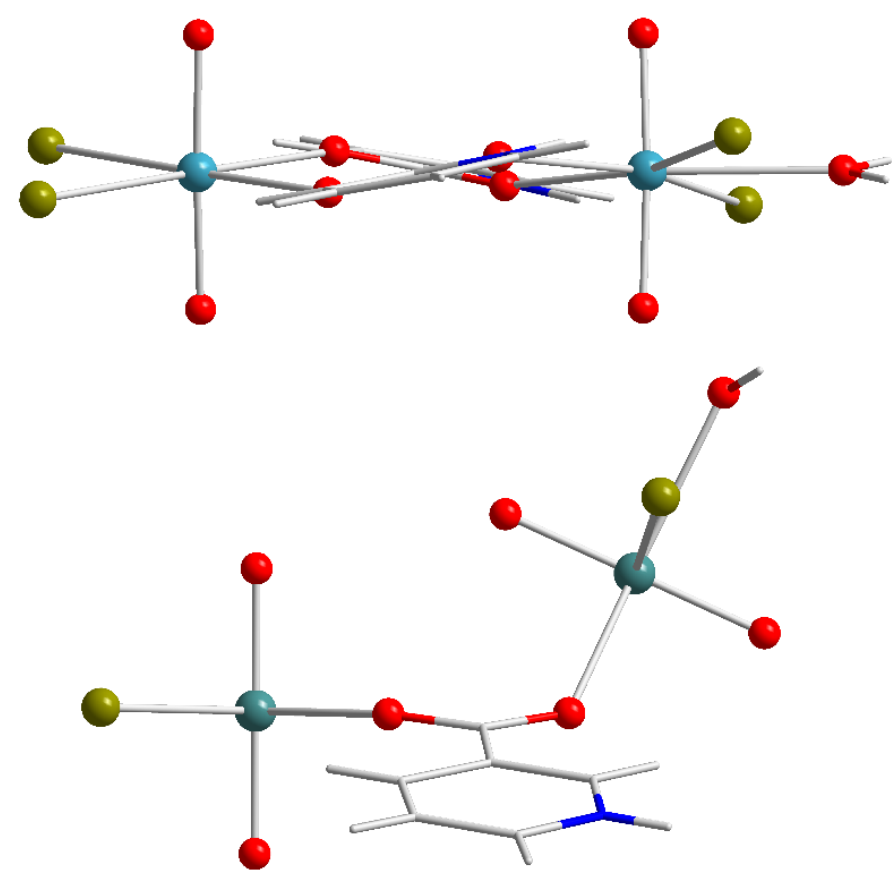

Figure S3. Geometries of the dinuclear units in the structures of compounds 1 (top) and 2 (bottom) as viewed along the axis connecting the carbon atoms of the carboxylic groups of the picolinic and nicotinic acid molecules (hydrogen atoms omitted for clarity)

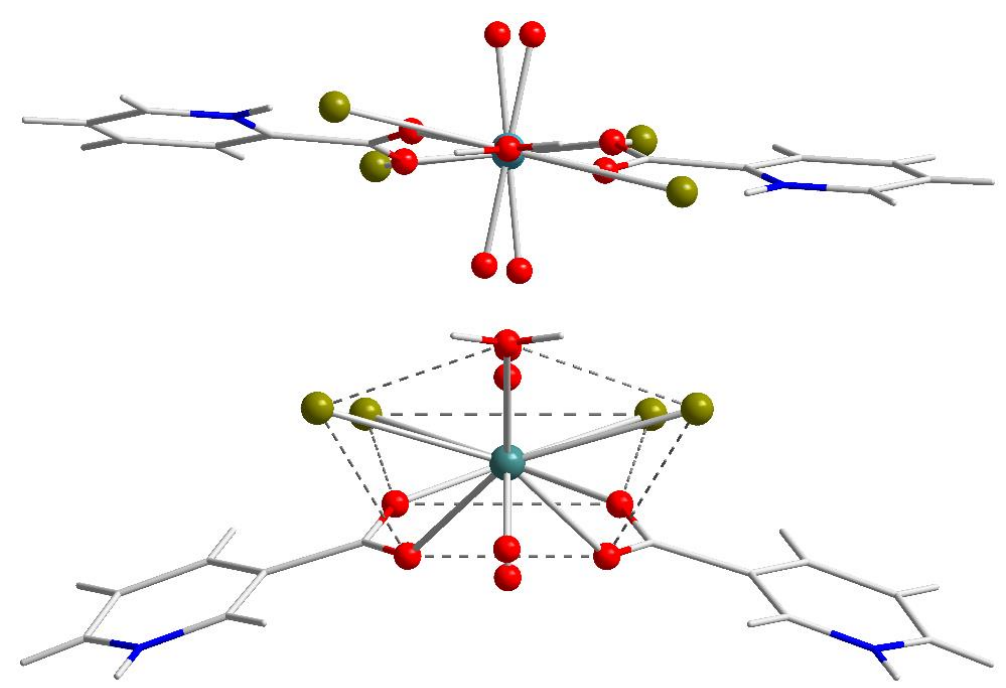

Figure S4. Geometries of the dinuclear units in the structures of compounds 1 (top) and 2 (bottom) as viewed along the axis connecting the $\mathrm{U}(1)$ and $\mathrm{U}(2)$ atoms 


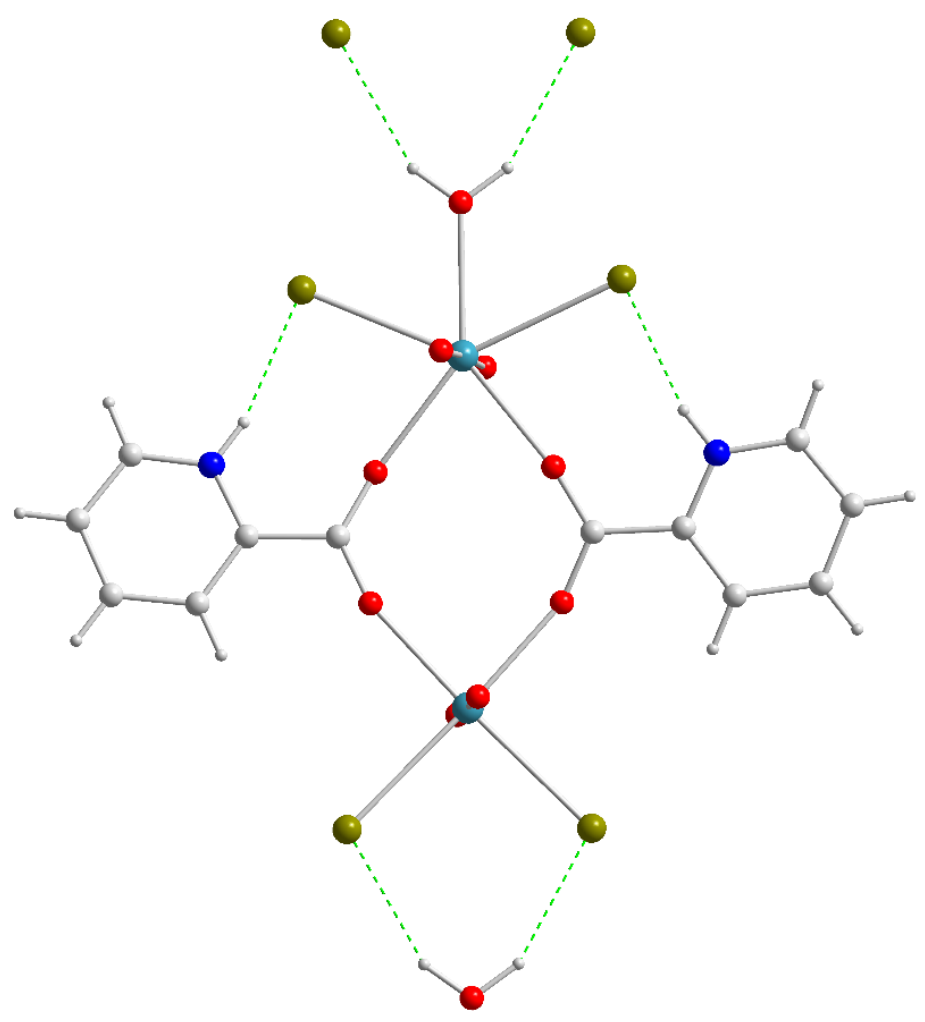

Figure S5. Hydrogen bonds in the structures of compound 1

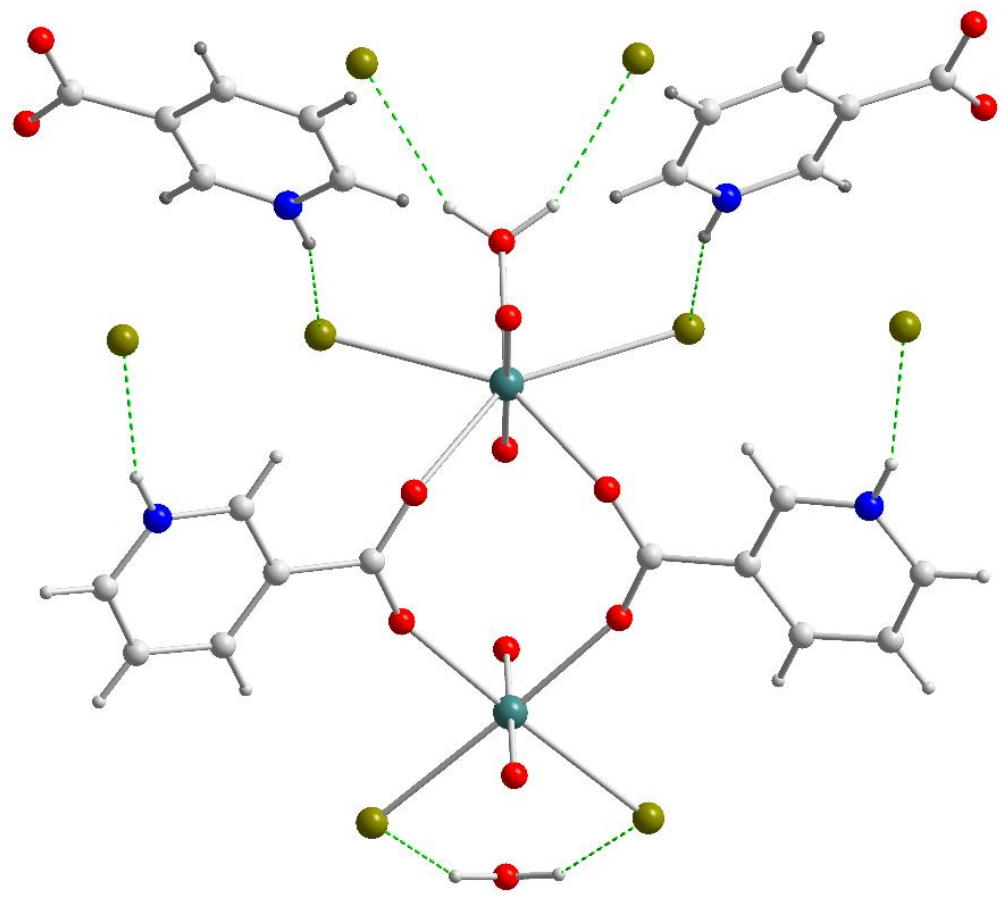

Figure S6. Hydrogen bonds in the structures of compound 2 

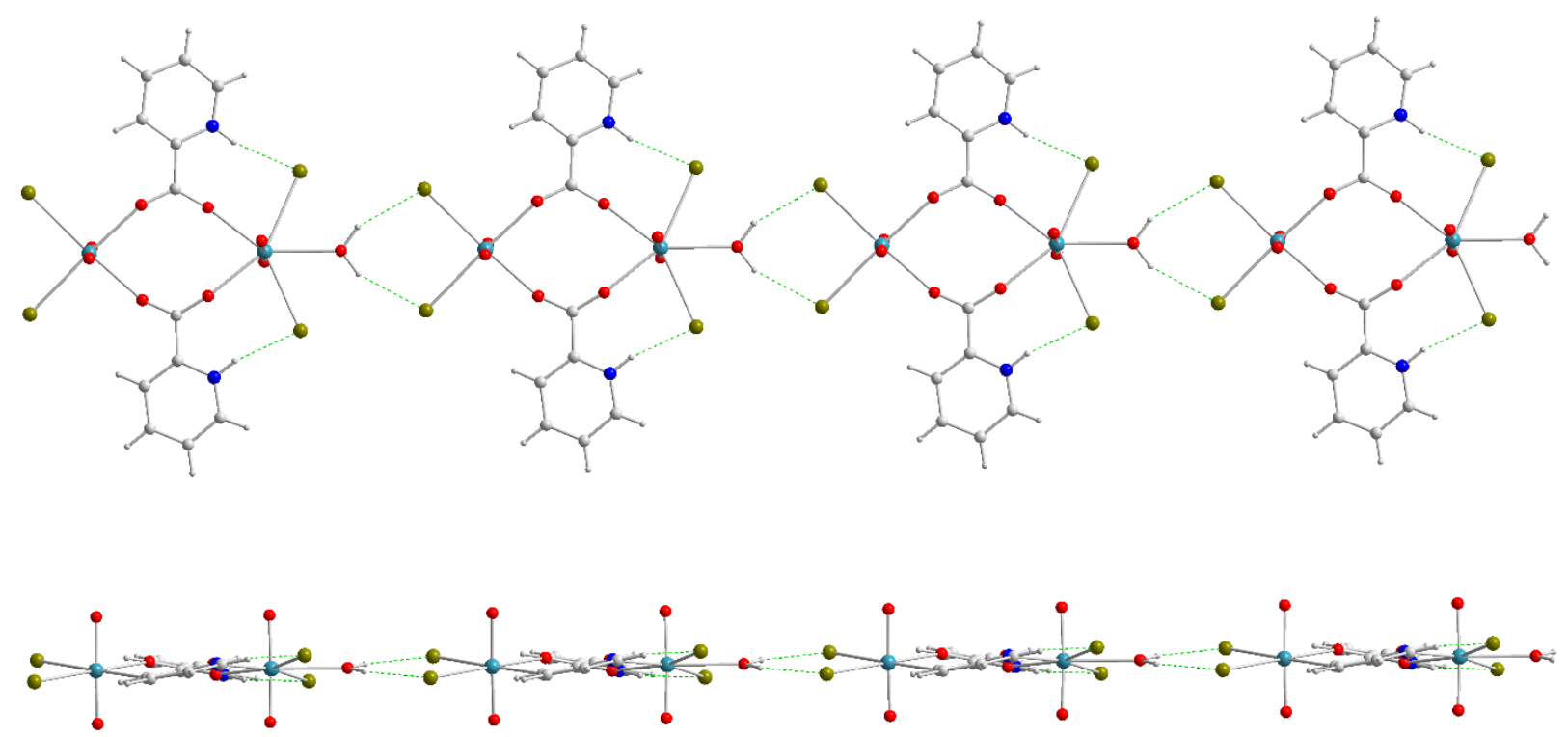

Figure S7. Hydrogen bonds assisted chains in the structures of compound 1 (top) and their planar geometry (bottom)
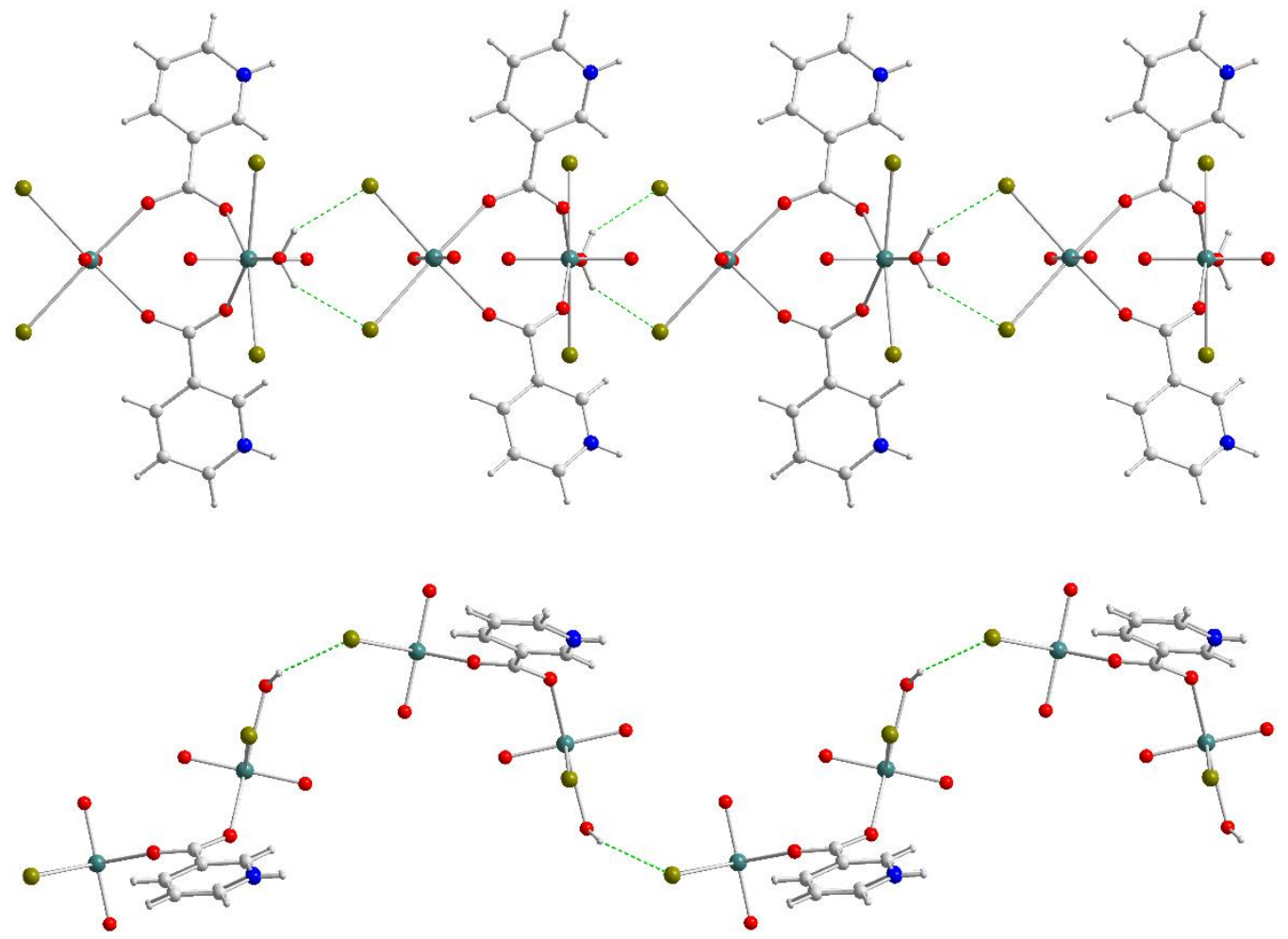

Figure S8. Hydrogen bonds assisted chains in the structures of compound 2 (top) and their curved geometry (bottom) 

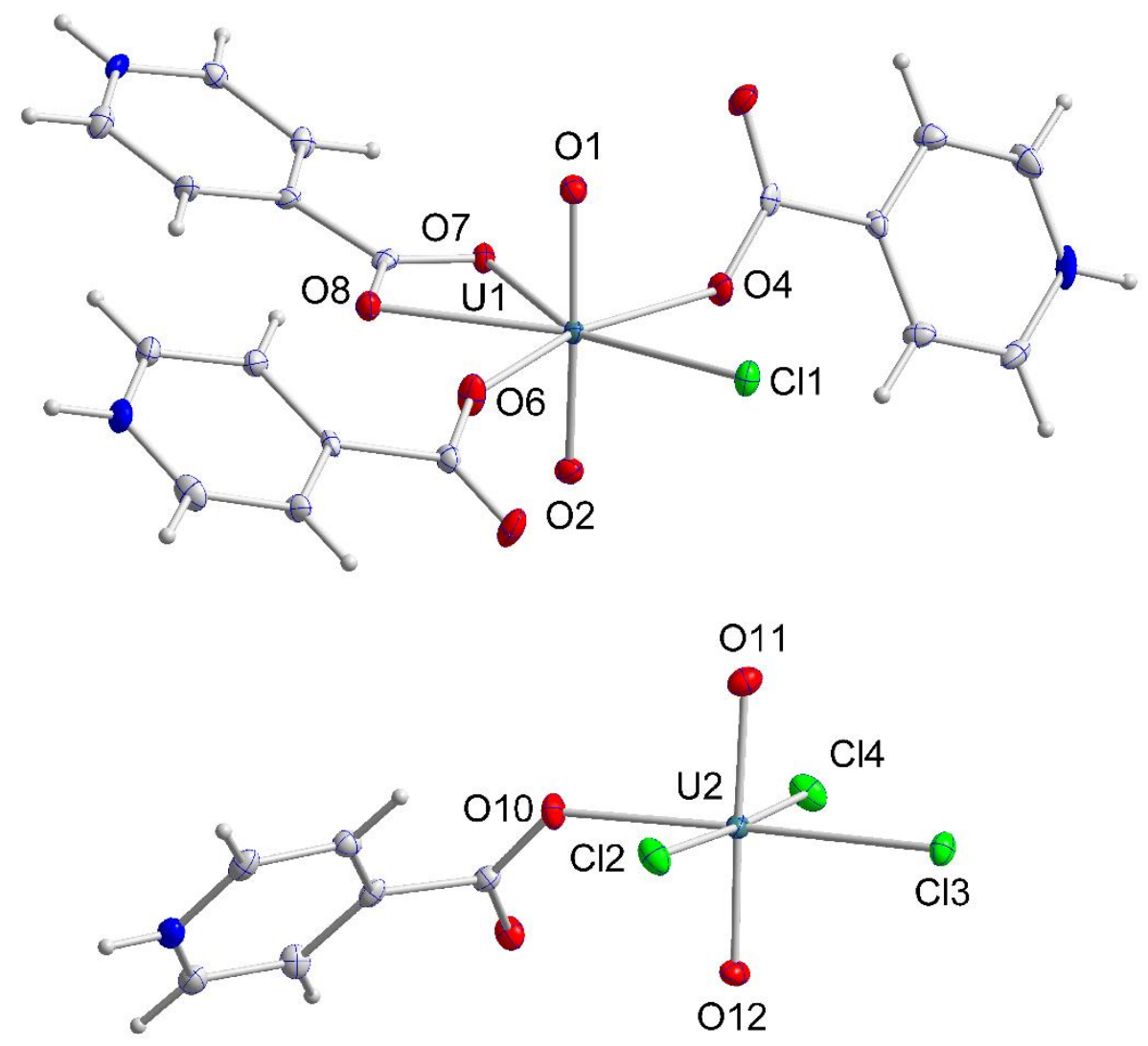

Figure S9. Thermal ellipsoid representation of the $\left[\mathrm{UO}_{2} \mathrm{Cl}(\mathrm{HisoNic})_{3}\right]^{+}$cation (top) and the $\left[\mathrm{UO}_{2} \mathrm{Cl}_{3}(\mathrm{HisoNic})\right]^{-}$anion (bottom) in the structure of compound $\mathbf{3}$ 
The substitution of the chloride ion with the fluoride ion in the system with isonicotinic acid resulted in the formation of a complex with a different composition, $\left[\left(\mathrm{UO}_{2}\right)_{3} \mathrm{~F}_{6}(\mathrm{HisoNic})\left(\mathrm{H}_{2} \mathrm{O}\right)\right] \cdot \mathrm{H}_{2} \mathrm{O}(4)$ (Fig. S8). There are three crystallographically unique uranium centers, all having pentagonal bipyramidal surroundings. The equatorial plane of the U(1) atom is formed by two oxygen atoms of a bidentate molecule of isonicotinic acid as well as three fluoride ions. The $U(2)$ atom is connected with four fluoride ions and a water molecule. The $U(3)$ atom is surrounded by five fluoride ions. All the fluoride ions act as bridging ligands joining the metal centers into 2D layers (Figs. S9, S10). Such a bridging behavior is typical for fluoride ions as compared to chloride and bromide ions, and a majority of uranyl fluorides exhibit higher dimensional structures. Interestingly, other uranyl fluorides with isonicotinic acid were previously reported, one of them, $\left[\left(\mathrm{UO}_{2}\right)_{2} \mathrm{~F}_{4}(\mathrm{HisoNic})\right] \cdot \mathrm{H}_{2} \mathrm{O}$, also having a layered structure. ${ }^{[12]}$ However, the layers in the $\left[\left(\mathrm{UO}_{2}\right)_{2} \mathrm{~F}_{4}(\mathrm{HisoNic})\right] \cdot \mathrm{H}_{2} \mathrm{O}$ have a different structure due to the bridging function of the isonicotinic acid molecule; both crystallographically unique uranium atoms are linked to an oxygen atom and four fluoride ions.

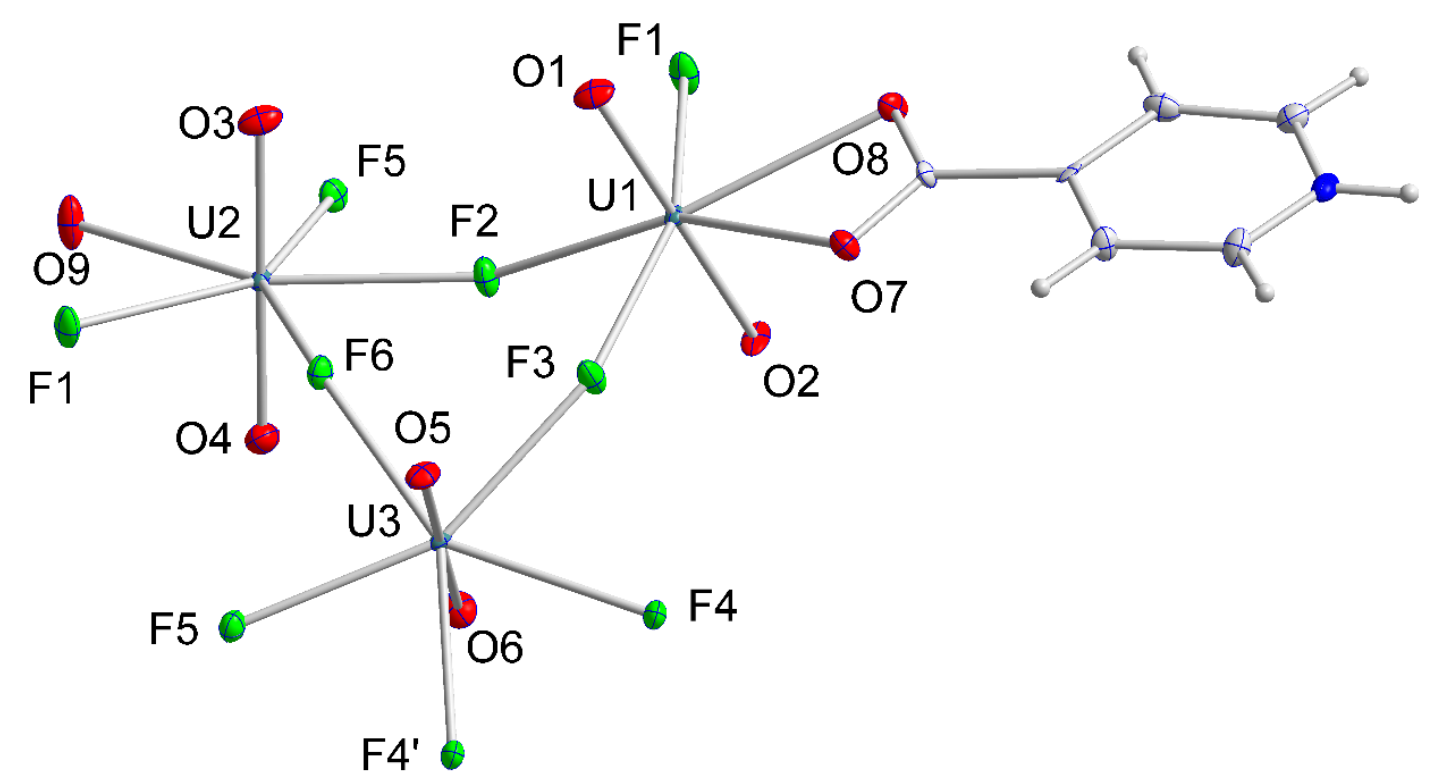

Figure S10. Thermal ellipsoid representation of a fragment of the crystal structure of 4 

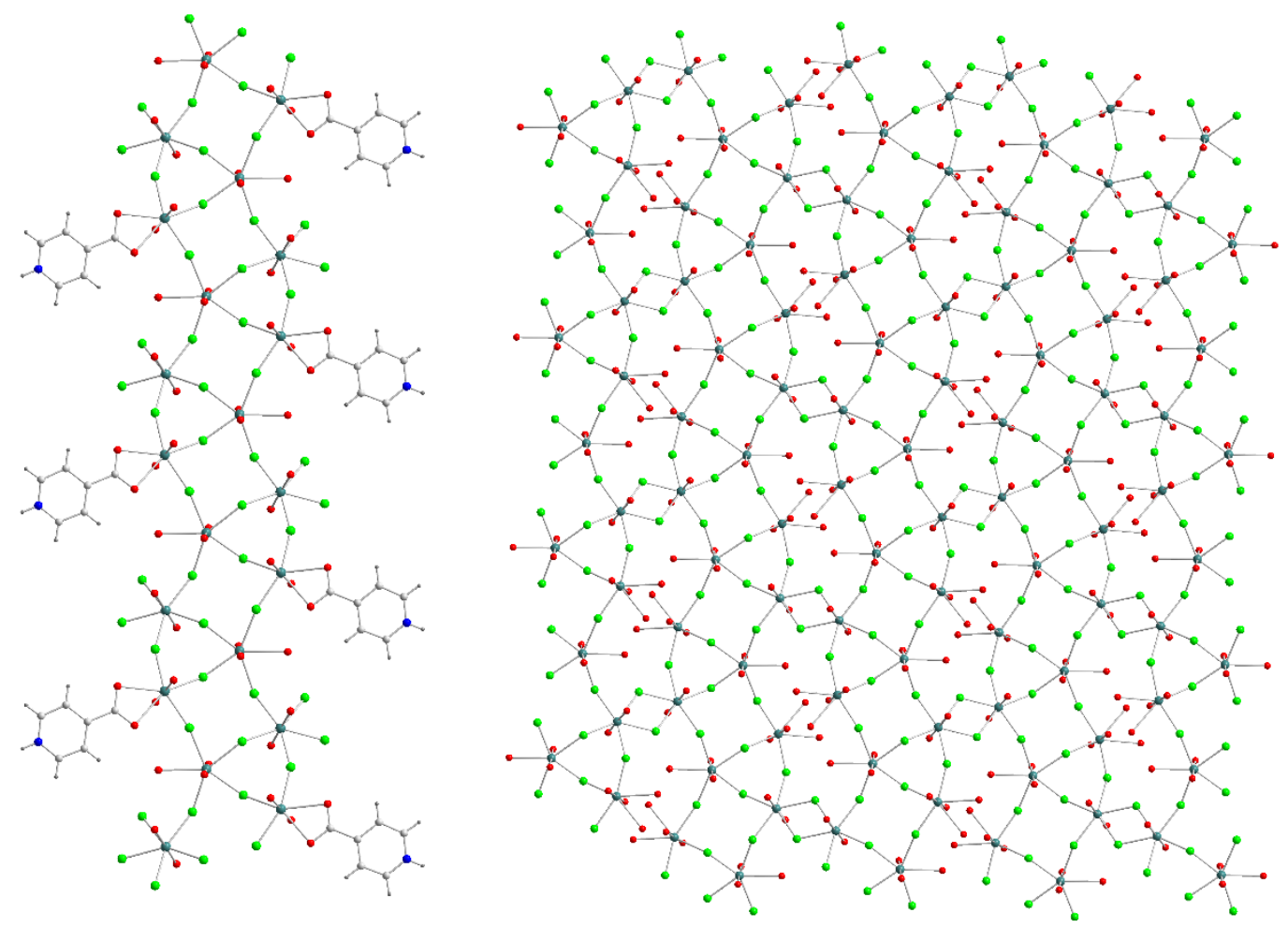

Figure S11. Infinite chains (left) in the structure of compound 4, which are joined into 2D layers via bridging fluoride ions (right, carbon and hydrogen atoms omitted for clarity)
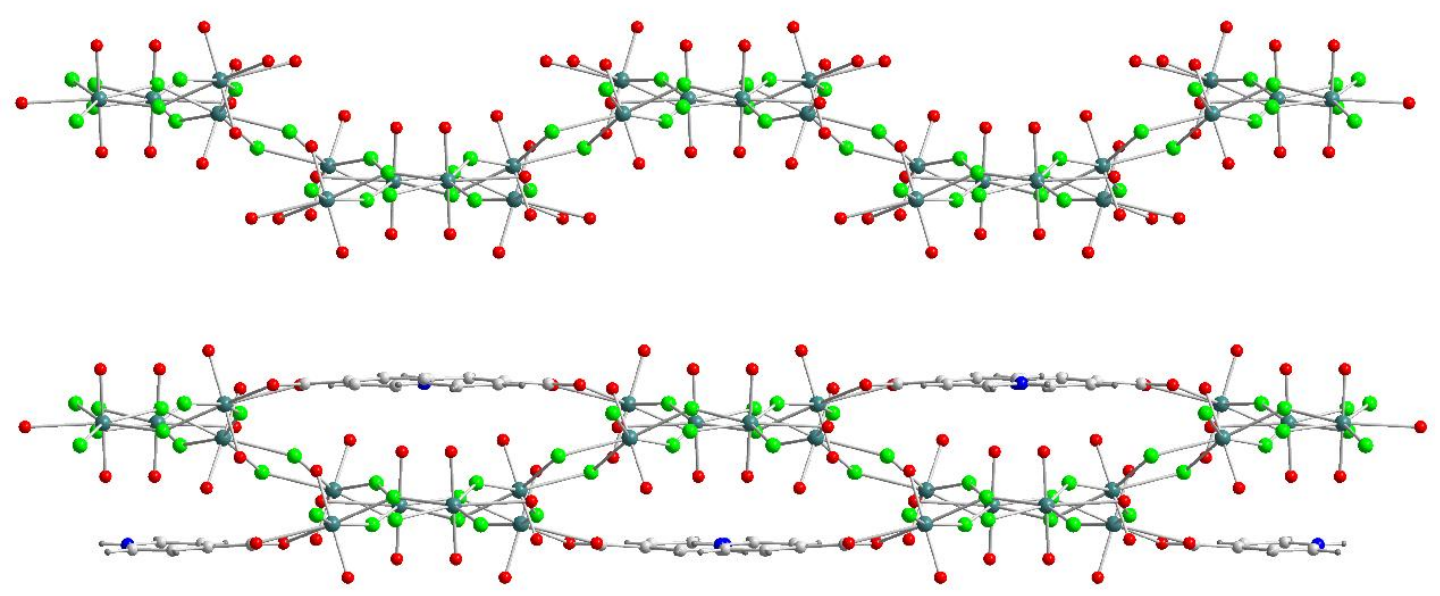

Figure S12 View of the layers along the chains in the structure of compound 4 (top: carbon and hydrogen atoms omitted for clarity), (bottom: molecules of isonicotinic acids are shown) 


\section{IR Spectroscopy}

The IR spectra of compounds 1-4 contain a large number of absorption bands mainly attributed to vibrations of the molecules of pyridinecarboxylic acids (Table S6, Figs. S11-S14). In all structures, molecules of picolinic, nicotinic, and isonicotinic acid present in the form of zwitterions due to the protonation of the nitrogen atom and the deprotonation of the carboxylic group. As a result, the $v(\mathrm{NH})$ stretching vibrations are observed in the $3250-3150 \mathrm{~cm}^{-1}$ range. These vibrations are especially prominent in the spectrum of compound $\mathbf{3}$, where they do not interfere with the $v(\mathrm{OH})$ vibrations of water molecules. The lowest values of $v(\mathrm{NH})$ were found in the spectra of compounds 1 and 2, which correlates with the presence of the hydrogen bonds between $\mathrm{NH}$ and $\mathrm{Br}$ in the structures. The $v(\mathrm{CH})$ vibrations of pyridine rings are located in the $3100-3000 \mathrm{~cm}^{-1}$ range. The $1700-1400 \mathrm{~cm}^{-1}$ region of the spectra contains $v\left(\mathrm{COO}^{-}\right)$vibrations of the carboxylategroups. As a result of the coordination with uranyl-ions, their frequencies are shifted to the lower energies when compared to the spectra of free molecules of picolinic, nicotinic, and isonicotinic acids $\left(1717,1708\right.$, and $\left.1712 \mathrm{~cm}^{-1}\right)$. This shift is the most noticeable in the spectrum of compound 4, which contains bidentate chelate anions only. This region of the spectra also contains $v(\mathrm{CC})$ and $v(\mathrm{CN})$ vibrations of pyridine rings. In the spectra of compounds $\mathbf{1}, \mathbf{2}$, and $\mathbf{4}$, the $\delta\left(\mathrm{H}_{2} \mathrm{O}\right)$ vibrations of water molecules appear as weak shoulders. Interestingly, the frequencies of the $v(\mathrm{CC})$ and $v(\mathrm{CN})$ vibrations are lower in the spectrum of the complexes with isonicotinic acid, although the nitrogen atoms do not coordinate with metal centers in all four structures. Spectra of free acids are similar, however, the frequencies of $v(\mathrm{CH}),(\mathrm{CC})$, and $v(\mathrm{CN})$ vibrations are different depending on the position of the hetero-atom and the carboxylic group, with the lowest values observed in the spectrum of nicotinic acid [3]. This effect can be attributed to the ligand coordination with the uranyl-ion, which influences not only on the carboxylic group vibrations but on the vibrations of the hetero-ring as well. Moreover, the molecule of isonicotinic acid seems to be the most sensitive to the coordination with a metal center. A similar effect was found for the alkali metal complexes with pyridncarboxylic acids [4]. The $1300-1000 \mathrm{~cm}^{-1}$ region of the spectra contain the bands corresponding to in-plane and out-of-plane vibrations of hetero-rings, which are sensitive to the coordination with metal atoms and show higher frequencies as compared to the spectra of free molecules. The $v\left(\mathrm{UO}_{2}\right)$ vibrations of uranyl ions are exhibited by the intense bands located in the 920-905 $\mathrm{cm}^{-1}$ region. These bands are narrow, despite of their multiplet character caused by the presence of crystallographically unique uranium atoms in the structures of the compounds. The weak bands ranging from 470 to $420 \mathrm{~cm}^{-1}$ may be assigned to the $v(\mathrm{U}-\mathrm{F})$ and $\mathrm{v}(\mathrm{U}-\mathrm{Cl})$ vibrations [5]. The corresponding $v(\mathrm{U}-\mathrm{Br})$ vibrations are expected to be located below $400 \mathrm{~cm}^{-1}$. 
Table S6. Main absorption bands in the IR spectra of compounds 1-4 $\left(\mathrm{cm}^{-1}\right)$ and their assignments

\begin{tabular}{|c|c|c|c|c|}
\hline Assignment & 1 & 2 & 3 & 4 \\
\hline$v(\mathrm{OH})$ & $3489-3310$ & $3500-3378$ & & 3509,3448 \\
\hline$v(\mathrm{NH})$ & 3192,3145 & 3170,3149 & 3242,3150 & 3216,3162 , \\
\hline$v(\mathrm{CH})_{\mathrm{pyr}}$ & $\begin{array}{l}3117,3080, \\
3004\end{array}$ & $\begin{array}{l}3125,3092, \\
3018\end{array}$ & $\begin{array}{l}3094,3074, \\
3004\end{array}$ & 3086,3040 \\
\hline$v(\mathrm{C}=\mathrm{O})$ & 1682 & 1672 & $\begin{array}{l}1688,1644 . \\
1622\end{array}$ & - \\
\hline$\delta\left(\mathrm{H}_{2} \mathrm{O}\right)$ & $1642 \mathrm{sh}$ & 1640 & & 1636 \\
\hline$v(\mathrm{CC})_{\mathrm{pyr}}+v(\mathrm{CN})_{\mathrm{pyr}}$ & $\begin{array}{l}1635,1609, \\
1575,1556, \\
1517\end{array}$ & $\begin{array}{l}1608,1590 \\
1538,1518\end{array}$ & $\begin{array}{l}1598,1565, \\
1552,1514\end{array}$ & $\begin{array}{l}1598,1584, \\
1559,1526, \\
1512\end{array}$ \\
\hline$v(\mathrm{COO}-)+\beta(\mathrm{CH})$ & $\begin{array}{l}1492,1426, \\
1374,1350\end{array}$ & $\begin{array}{l}1492,1447, \\
1427,1408, \\
1390,1315\end{array}$ & $\begin{array}{l}1494,1485, \\
1358\end{array}$ & $\begin{array}{l}1472,1436, \\
1403,1300\end{array}$ \\
\hline$\delta(\mathrm{COO})$ & 1299,1241 & $1270,1247 \mathrm{sh}$ & 1298,1243 & 1286 \\
\hline$v(\mathrm{CC})_{\text {breathing }}+\delta(\mathrm{CH})_{\mathrm{pyr}}$ & $\begin{array}{l}1146,1078, \\
1005\end{array}$ & $\begin{array}{l}1180,1112, \\
1034,1014\end{array}$ & $\begin{array}{l}1228,1185, \\
1146,1094, \\
1078,1052\end{array}$ & $\begin{array}{l}1248,1227, \\
1157,1092, \\
1008\end{array}$ \\
\hline $\begin{array}{l}v(\mathrm{CC})_{\text {breathing }} \\
v\left(\mathrm{UO}_{2}\right)\end{array}$ & 916,907 & 919,910 & 915,910 & $\begin{array}{l}956 \\
916,912,906\end{array}$ \\
\hline $\begin{array}{l}\gamma(\mathrm{CH}) \\
\gamma(\mathrm{COO})\end{array}$ & $\begin{array}{l}892 \mathrm{sh}, 861,836, \\
824,769,754\end{array}$ & $\begin{array}{l}873,858,785, \\
701\end{array}$ & $\begin{array}{l}862,837,822 \\
771,754\end{array}$ & $\begin{array}{l}876 \text { sh, } 858, \\
783\end{array}$ \\
\hline $\begin{array}{l}\text { ring def } \\
v(\mathrm{U}-\mathrm{X})\end{array}$ & 678 & $\begin{array}{l}628,608 \\
-\end{array}$ & $\begin{array}{l}692,681,645 \\
459,427\end{array}$ & $\begin{array}{l}687,670,625 \\
474,449\end{array}$ \\
\hline
\end{tabular}




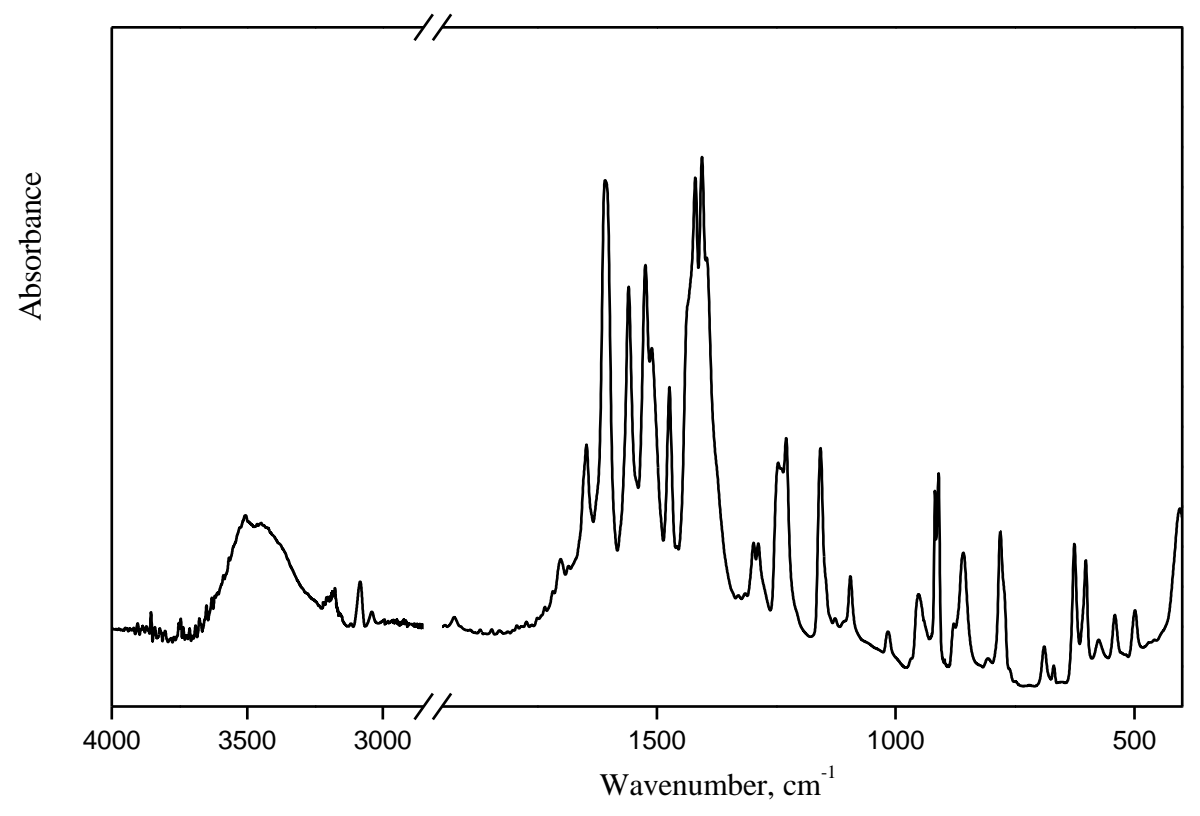

Figure S13. Infrared spectrum of compound 1

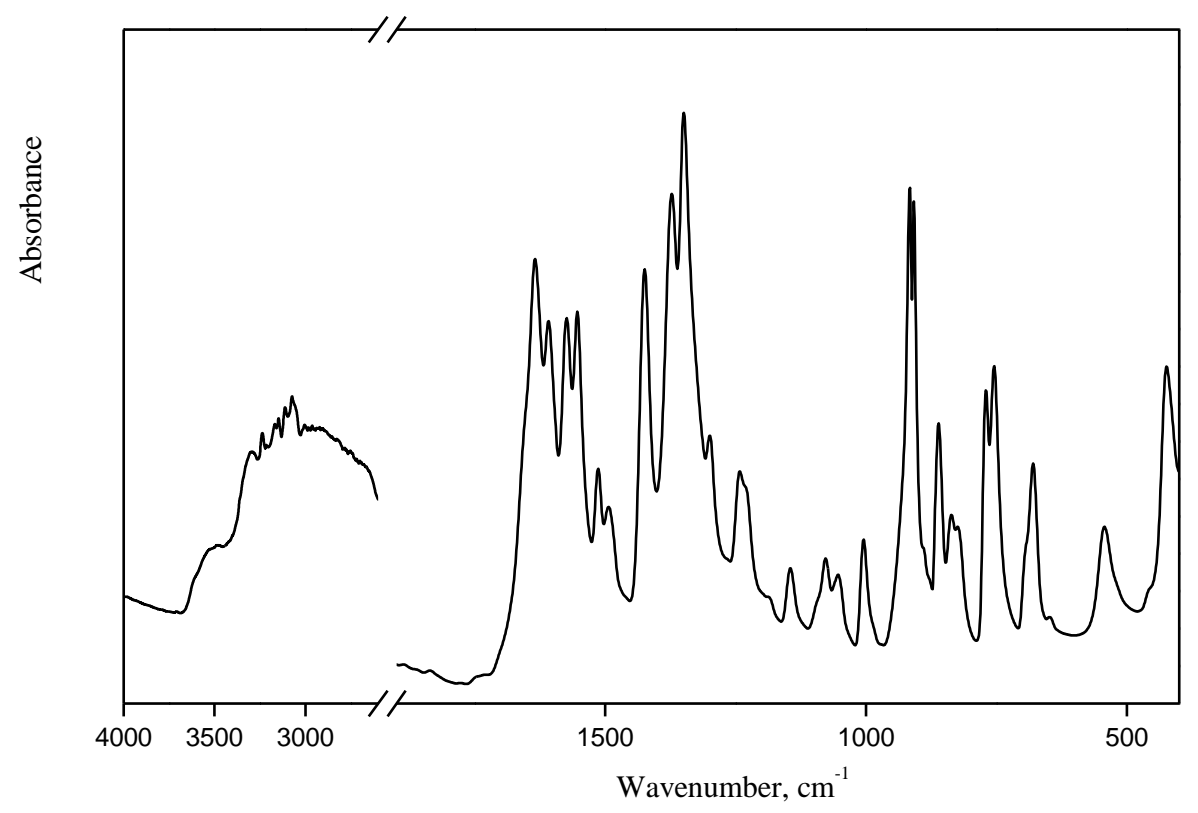

Figure S14. Infrared spectrum of compound 2 


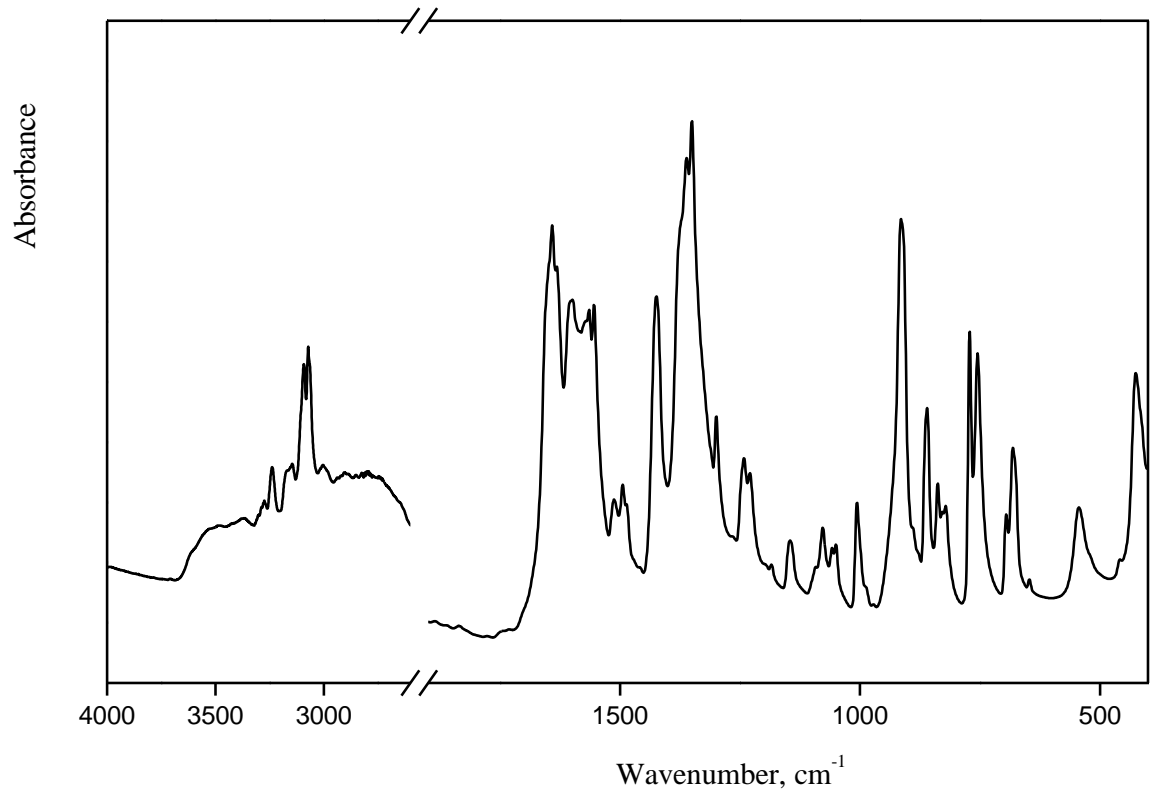

Figure S15. Infrared spectrum of compound $\mathbf{3}$

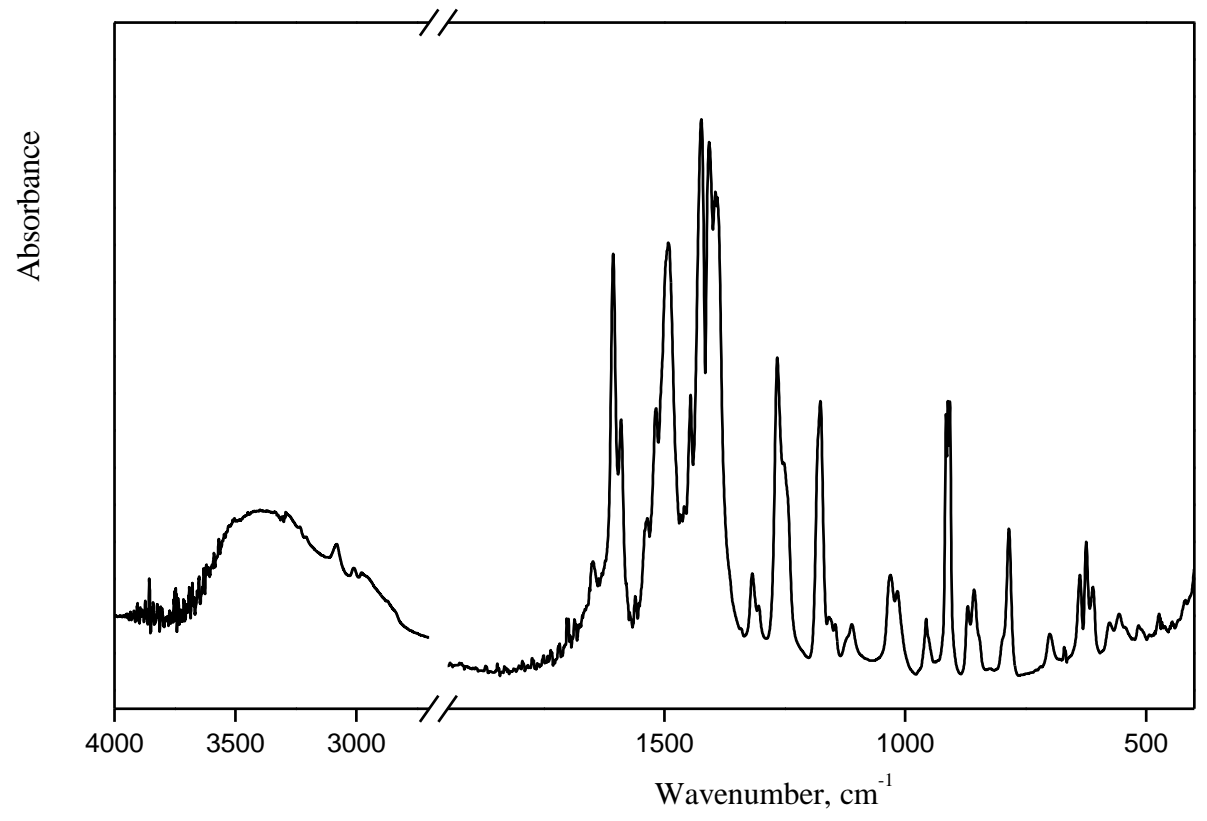

Figure S16. Infrared spectrum of compound 4 
Table S7. Maxima of spectral bands in the UV-vis and luminescence spectra of compounds 1-4 (nm)

\begin{tabular}{lll}
\hline Compound & Absorption & Luminescence \\
\hline 1 & $398.4,409.7, \mathbf{4 2 1 . 8}, 434.8,451.9,469.2,485.1$ & \\
2 & $396.2,408.1,414.3, \mathbf{4 2 0 . 7}, 433.6,452.8,472.7,489.3$ & \\
3 & $395.8,406.1,417.4, \mathbf{4 2 9 . 4}, 442.2,458.8,476.1,491.9$ & $498,522,544,576$ \\
4 & $391.6,402.4,414.1, \mathbf{4 2 6 . 1}, 435.2,438.8,455.6,473.1,489.3$ & $506,525,556,577$ \\
\hline
\end{tabular}

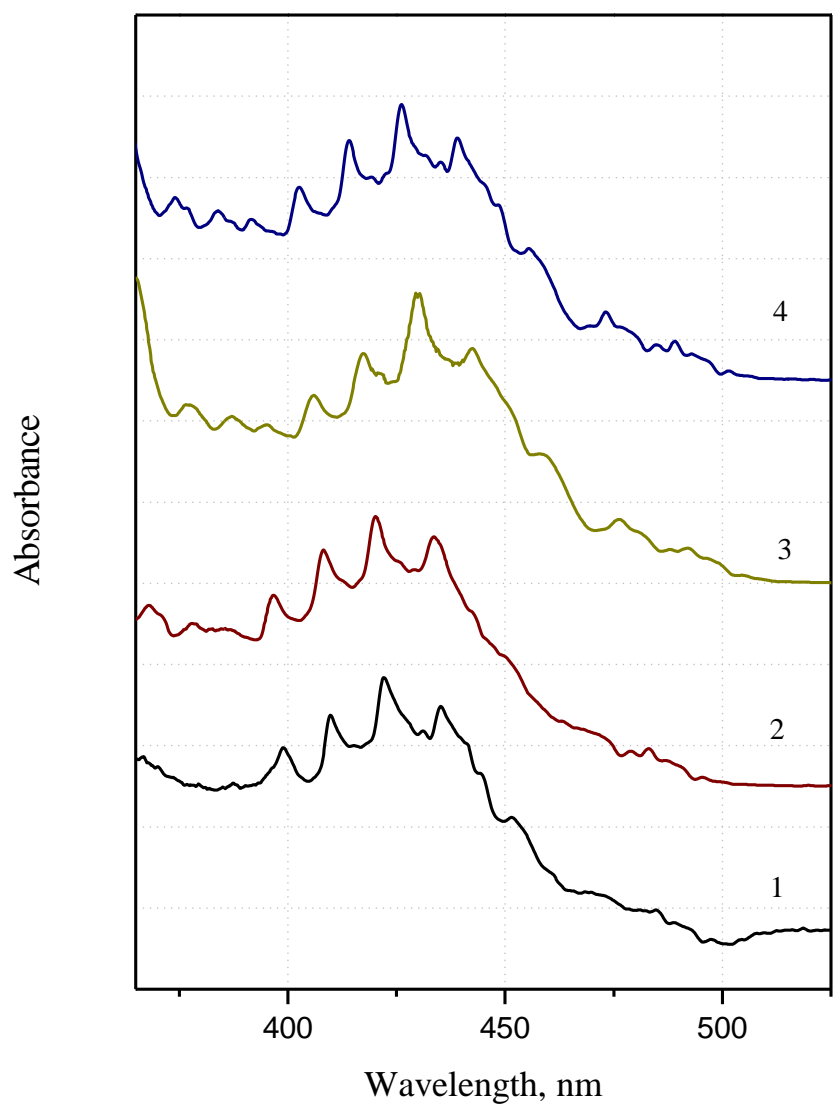

Figure S17. Optical spectra of compounds 1 - 4 


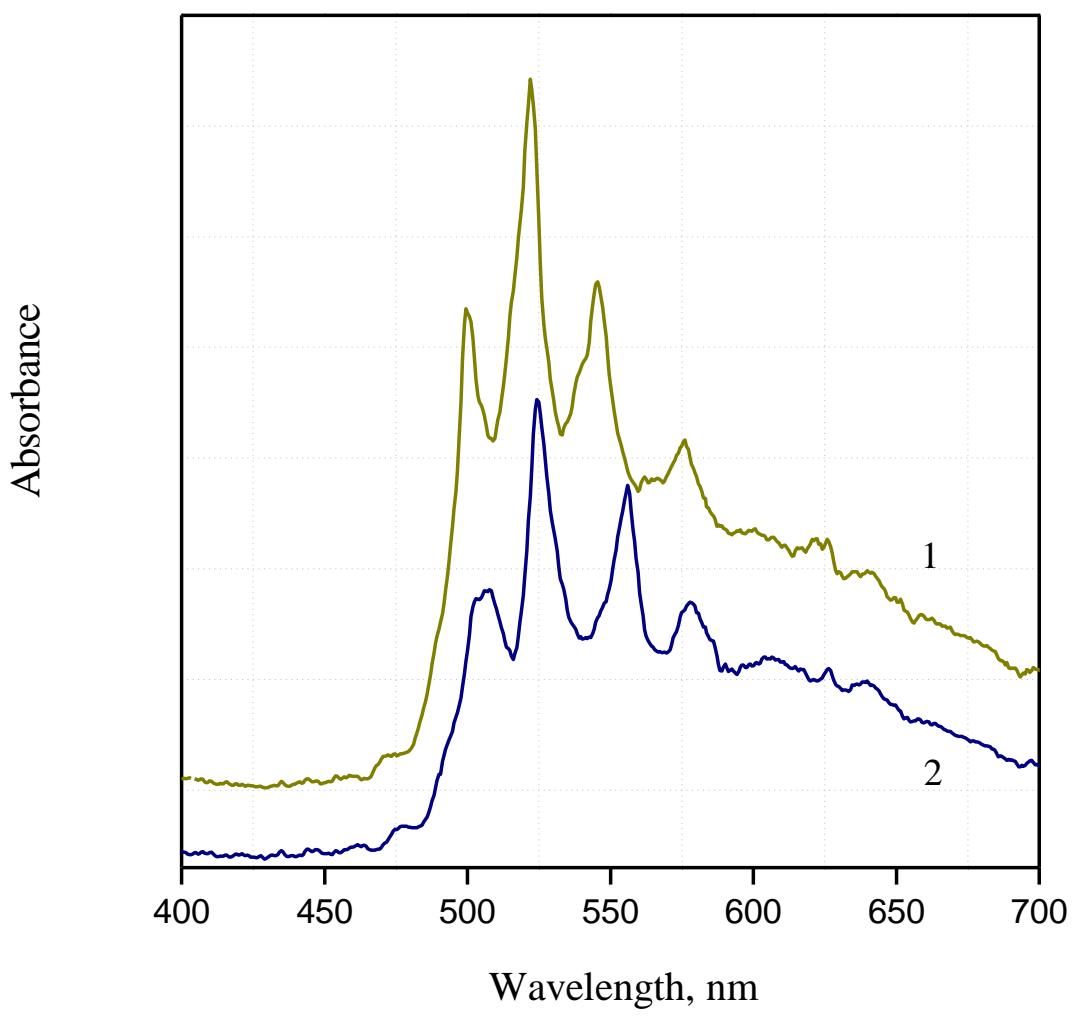

Figure S18. Luminescence spectra of $\left[\mathrm{UO}_{2} \mathrm{Cl}(\mathrm{HisoNic})_{3}\right]\left[\mathrm{UO}_{2} \mathrm{Cl}_{3}(\mathrm{HisoNic})\right]$ (curve 1) and $\left[\left(\mathrm{UO}_{2}\right)_{3} \mathrm{~F}_{6}(\mathrm{HisoNic})\left(\mathrm{H}_{2} \mathrm{O}\right)\right] \cdot \mathrm{H}_{2} \mathrm{O}$ (curve 2) 


\section{REFERENCES}

1 SADABS; Bruker AXS Inc.: Madison, Wisconsin, 2001

2 Sheldrick, G. M. Crystal structure refinement with SHELXL. Acta Cryst. C 2015, 71, 3-8

3 Koczoń, P.; Dobrowolski, J. Cz.; Lewandowski, W.; Mazurek, A. P. Experimental and theoretical IR and Raman spectra of picolinic, nicotinic and isonicotinic acids. J. Mol. Struct. 2003, $655,89-95$

4 Lewandowski, W.; Świderski, G.; Świslocka, R.; Wojtulewski, S.; Koczoń, P. Spectroscopic (Raman, FT-IR, and NMR) and theoretical study of alkali metal picolinates. J. Phys. Org. Chem. 2005, 18, 918-928

5 Marshell, J. Infrared Investigation of Uranyl Chloride and Uranyl Fluoride. Asian J. Chemistry 2007, 19, 4645-4648 